\title{
Effect of Incorporating Whey Protein Concentrate on Chemical, Rheological and Textural Properties of Ice Cream
}

\author{
El-Zeini Hoda $\mathbf{M}^{1 *}$, Moneir El-Abd $\mathbf{M}^{1}$, Mostafa $\mathrm{AZ}^{2}$ and Yasser El-Ghany $\mathrm{FH}^{2}$ \\ ${ }^{1}$ Dairy Science and Technology Department, Faculty of Agriculture, Cairo University, Cairo, Egypt \\ ${ }^{2}$ Food Technology Research Institute, Agriculture Research Center, Giza, Egypt
}

\begin{abstract}
Effect of whey protein concentrate as a partial substitution of milk solids not fat in ice cream formula was investigated by replacing 1, 2, 3 and $4 \%$ of mix solid not fat. Mixes and resultant ice cream samples were evaluated for their chemical, physicochemical, and rheological properties as well as the sensory quality attributes. Implementing whey protein concentrate in ice cream recipes increased total protein, freezing point and consistency, while, ash, lactose, specific gravity decreased significantly $(p<0.001)$. Apparent viscosity as well as flow time of mixes was significantly $(p<0.001)$ increased with substitution of milk solid not fat by whey protein concentrate. Flow behavior was also affected showing higher yield stress. The consistency coefficient (k) was more affected by the presence of whey protein concentrate in the recipe than the flow behavior index ( $n$ ). However, increasing whey protein concentrate decreased hardness, cohesiveness, gumminess and chewiness values in texture profile analysis, while there were increase in adhesiveness, springiness and hesion values in fresh ice cream samples over that of stored. The ice cream became smoother and highly acceptable for the panelists by replacing milk solid not fat with whey protein concentrate up to $3 \%$. From the data obtained, it could be recommended that ice cream can be produced with high quality by substituting milk solid not fat with whey protein concentrate up to $3 \%$.
\end{abstract}

Keywords: Ice cream; Whey protein concentrate; Rheological properties; Texture profile analysis

\section{Introduction}

Ice cream is a complex colloidal food that composes of four distinct phases: a continuous serum phase known as a matrix, and three distinct dispersed phases corresponding to fat droplets, ice crystals and air cells [1]. Whey protein concentrate (WPC), a by-product from cheese production, is used in ice cream production to develop a better quality. Because of its good water binding property, WPC delays development of coarseness and increases ice cream mix viscosity. Moreover, the presence of WPC in ice cream could enhance fine dispersion of air cells and lower the ice crystal size in ice cream owing to its foaming property. Furthermore, WPC also lowers surface tension, stabilizes the fat emulsion, controls fat destabilization and enhances partial coalescence due to the emulsifying properties of protein [2]. Patel et al. [3] study the effect of adding WPC to vanilla ice cream and found that WPC could improve physical properties and sensory quality of ice cream by resisting changes in ice cream during storage, enhancing its nutritional value, and increasing consumers' acceptance.

Rheology reflects the manner in which food materials respond to an applied stress or strain and it generally relates to the flow properties of food materials. Rheological properties are important in determining the quality of finished goods; also, they are related to sensory perception. Elucidation of relationships between structural changes during processing, rheology, and sensory perception is very important. For dairy foods, the rheology of fluid and plastic products is relevant to consumer acceptability. Texture profile analysis (TPA) method is widely used for texture evaluation of food products. Human eating action normally consists of several bites. In order to better describe the eating actions of human, the TPA test performs two bites every bite includes loading and unloading cycle. Many research groups have conducted instrumental texture profile analysis (TPA) for assessing the textural properties of food [4].

So, the aims of this study were, to evaluate the effect of different substitution levels of WPC on the chemical composition, texture, rheological properties of ice cream, and to determine the changes of the rheological model as a result of the substitution of MSNF with different WPC\%. Moreover, to establish the relationships between chemical composition and rheological behavior of ice cream to set the best substitution level of WPC.

\section{Materials and Methods}

\section{Materials}

Fresh buffalo's skim milk ( $90.9 \%$ moisture, $0.1 \%$ fat, $3.4 \%$ protein, $4.9 \%$ lactose and $0.7 \%$ ash) and fresh concentrated cream $(29.4 \%$ moisture, $67 \%$ fat, $1.3 \%$ protein, $1.7 \%$ lactose and $0.6 \%$ ash) were obtained from the herd of Faculty of Agriculture, Cairo University and used as an ingredient for preparing the ice cream mixes. Low heat skim milk powder (3.8\% moisture, $0.8 \%$ fat, $33.4 \%$ protein, $54.1 \%$ lactose and $7.9 \%$ ash) was obtained from Abou El-Hool-Import/Export Co., Cairo, Egypt. Whey protein concentrate powder (4.7\% moisture, $5.9 \%$ fat, $77.7 \%$ protein, $9.1 \%$ lactose and $2.6 \%$ ash) was supplied by Davisco Foods International, Inc, USA. Commercial grade sugar cane was obtained from the local market, Sodium carboxymethyl cellulose (CMC) as a stabilizer was obtained from Mifad Company, Giza, Egypt. Vanilla was obtained from the local market and used to flavour final ice cream.

*Corresponding author: El-Zeini Hoda M, Dairy Science and Technology Department, Faculty of Agriculture, Cairo University, Cairo, Egypt, Tel: +201000752906; E-mail: dr_hodazeini@yahoo.com

Received January 06, 2016; Accepted January 27, 2016; Published February 01,2016

Citation: El-Zeini Hoda M, Moneir El-Abd M, Mostafa AZ, Yasser El-Ghany FH (2016) Effect of Incorporating Whey Protein Concentrate on Chemical, Rheological and Textural Properties of Ice Cream. J Food Process Technol 7 : 546. doi:10.4172/2157-7110.1000546

Copyright: @ 2016 El-Zeini Hoda M, et al. This is an open-access article distributed under the terms of the Creative Commons Attribution License, which permits unrestricted use, distribution, and reproduction in any medium, provided the original author and source are credited. 
Citation: El-Zeini Hoda M, Moneir El-Abd M, Mostafa AZ, Yasser El-Ghany FH (2016) Effect of Incorporating Whey Protein Concentrate on Chemical, Rheological and Textural Properties of Ice Cream. J Food Process Technol 7: 546. doi:10.4172/2157-7110.1000546

\section{Manufacture of ice cream}

Ice cream mix contained $8 \%$ fat, $12 \%$ milk solid not fat, $15 \%$ sucrose, $0.25 \%$ stabilizer. Skimmed milk powder was substituted with WPC at 1.0, 2.0, 3.0 and $4.0 \%$ of dried milk solids not fat in the base mix (Table 1).

\section{Methods}

Total solids, total protein content and ash were determined according to AOAC [5]. Titratable acidity of mixes was determined according to Lawrance [6]. Lactose content was determined according to Arbuckle [7]. Fat content was determined according to Divide [8]. Values of $\mathrm{pH}$ were measured using a digital laboratory $\mathrm{pH}$ meter (HI 93 1400, Hanna instruments). The specific gravity of mix was measured using a bottle pyconometer as described by Winton [9] at $20^{\circ} \mathrm{C}$. The weight per gallon (lb) of ice cream mixes and the final frozen products were calculated according to Kessler [10] by multiplying the specific gravity by the factor of 8.34 . Freezing point of ice cream mix was measured as described in FAO [11].

Consistency of the mix was measured as the time (sec) to empty a 50-ml pipette according to Lawrance [6]. Apparent viscosity of mix was determined according to Petersen et al. [12] using a Brookfield viscometer (Brookfield DVIII Ultra Programmable Rheometer equipped with a spindle No. SC4-21 in $250 \mathrm{ml}$ cup. Approximately 24 hours after preparation of the ice cream mixes, viscosity and shear stress were measured periodically at shear rates ranging from 18.6 to 186 $\mathrm{sec}^{-1}$. At each shear rate, shear stress was recorded after two minutes of spindle rotation to ensure a steady reading. All samples were adjusted at $20 \pm 1^{\circ} \mathrm{C}$ before loading in the viscometer device. Collected shear stress/shear rate data was exported to a Microsoft Excel spreadsheet and used to generate Power Law equation and the Herschel-Bulkley equation. Power Law fluids are characterized by a straight line log-log plot of shear stress vs. shear rate, according to the Power Law equation. A straight line plot of shear stress vs. the shear rate allows application of the Herschel-Bulkley equation which usually used to determine the yield stress. Overrun of ice cream samples was calculated by using the method given by Benezech [13].

$$
\text { Overrun }=\frac{\text { weight of mix }- \text { weight of the same volume of ice cream }}{\text { weight of the same volume of ice cream }} \times 100
$$

\section{Texture profile analysis}

Texture profile analysis test of ice cream samples was done using a Universal Testing Machine (TMS-Pro) equipped with 1000 N (250 lbf) load cell and connected to a computer programmed with Texture Pro $^{\mathrm{TM}}$ texture analysis software (program, DEV TPA With hold). A flat rod probe ( $49.95 \mathrm{~mm}$ in diameter) was used to uniaxial compress the ice cream samples to $50 \%$ of their original height. The texture profile

\begin{tabular}{|c|c|c|c|c|c|}
\hline \multirow{2}{*}{ Ingredients } & \multirow{2}{*}{ Control } & \multicolumn{4}{|c|}{ Level of substitution (g/kg mix) } \\
\cline { 3 - 6 } & & $\mathbf{T}_{\mathbf{1}}$ & $\mathbf{T}_{\mathbf{2}}$ & $\mathbf{T}_{\mathbf{3}}$ & $\mathbf{T}_{\mathbf{4}}$ \\
\hline Sugar & 150 & 150 & 150 & 150 & 150 \\
\hline Stabilizer & 2.5 & 2.5 & 2.5 & 2.5 & 2.5 \\
\hline Fresh skim milk & 670.38 & 670.38 & 670.38 & 670.38 & 670.38 \\
\hline Cream & 117.69 & 117.69 & 117.69 & 117.69 & 117.69 \\
\hline Dried skim milk & 59.43 & 48.94 & 38.16 & 27.08 & 17.10 \\
\hline WPC $\mathbf{8 0}$ & 0.00 & 11.18 & 22.17 & 33.05 & 43.04 \\
\hline Total & 1000 & 1000.69 & 1000.9 & 1000.7 & 1000.71 \\
\hline
\end{tabular}

$\mathrm{T}_{1}, \mathrm{~T}_{2}, \mathrm{~T}_{3}, \mathrm{~T}_{4}$ : Corresponding to $1,2,3$ and $4 \%$ WPC substitution of milk solid not fat

Table 1: Formulation of different ice cream mixes with WPC as a substitute of milk solid not fat (g/ kg mix). analysis test set condition was adjusted to a test speed $50 \mathrm{~mm} / \mathrm{sec}$, trigger force $1 \mathrm{~N}$, deformation $40 \%$ and holding $2 \mathrm{sec}$ between cycles. Test was carried out on samples which left in refrigerator until the temperature became $-12^{\circ} \mathrm{C}$.

Sensory evaluation of resultant ice cream was judged by 10 staff members of the Food Technology and Research Center, Dairy Department. The evaluation comprised of flavor (45 points), body and texture (35 points) melting properties (10) and colour (10) [6].

\section{Statistical analysis}

Data were analysed statistically using the MSTAT-C (ver 2.10, MSU, USA.) package on a personal computer. All experiments were carried out in triplicates. Differences were considered significant at $\mathrm{p}<0.05$.

\section{Results and Discussion}

\section{Properties of ice cream mixes}

Chemical composition of ice cream mixes with whey protein concentrate as a substitution of MSNF in base formula is shown in Table 2. Fat was adjusted in all mixes to almost $8 \%$ for recipe formula during the procedures.

The average value of protein contents in different ice cream treatments was stated in Table 2. A proportional replacement of MSNF with WPC resulted in a significant increase $(p<0.001)$ of protein contents of ice cream mixes. The increase mainly due to the higher protein content in added WPC (77.7\%) compared with SMP (33.4\%). Among treatments with WPC, the protein content was significantly affected by the ratio added ( $\mathrm{LSD}=0.084$ at $0.05 \alpha$ level). The total protein content increased in an ascending order with increasing the ratio of WPC substitution being the highest at 4\% WPC with a high correlation (0.999). Regression analysis student $\mathrm{T}$ test showed a significant difference for the treatment of ice cream mix with variable contents of WPC $(p<0.001)$. These data agreed with the findings of Awad [14] and Suneeta [15].

The usage of WPC as a MSNF replacer leads to a significant reduction $(\mathrm{p}<0.001)$ in ash content as shown in Table 2 . Ash contents decreased in ice cream mixes with the addition of WPC ratio. This decrease could be due to the differences in ash contents of WPC (2.6\%) and SMP (7.9\%). Coefficient correlation (-0.985) showed a tight inverse relationship between WPC and ash\%. The obtained results are in a harmony with the findings of Awad [14] and Patel et al. [3]. Lactose values decreased by increasing the substitution level of WPC in the mixes which due to a less content of lactose in WPC (9.1\%) than in SMP (54\%). However, WPC with low lactose content can be safely used at higher levels without concerning of sandiness development defect in ice cream [16]. The proportional use of WPC as a MSNF replacer leaded to a significant differences in lactose content $(\mathrm{p}<0.001)$ with a high negative correlation (-0.991). Among treatments, significant differences were found as a result of increasing WPC\% (LSD $=0.1975$ at $\alpha=0.050$ ).

\section{Physicochemical properties}

Acidity and $\mathbf{p H}$ values: Titratable acidity values of ice cream mix increased gradually from 0.21 to $0.26 \%$ (Table 3 ). The results showed that within treatments the acidity values differed insignificantly for the control, $\mathrm{T}_{1}, \mathrm{~T}_{2}$ and $\mathrm{T}_{3}$, while $\mathrm{T}_{4}$ significantly differed from the rest of the treatments $(\mathrm{LSD}=0.01883$ at 0.05 a level). Incorporating WPC in the ice cream formula increased the acidity values significantly 


\begin{tabular}{|c|c|c|c|c|c|}
\hline Treatments & Total solids & Fat & Total protein & Ash & Lactose content \\
\hline Control & 36.96 & 8.23 & $4.37^{\mathrm{e}}$ & $1.073^{\mathrm{a}}$ & $7.98^{\mathrm{a}}$ \\
\hline $\mathbf{T}_{1}$ & 36.37 & 8.23 & $4.94^{\mathrm{d}}$ & $0.943^{\mathrm{b}}$ & $7.24^{\mathrm{b}}$ \\
\hline $\mathbf{T}_{\mathbf{2}}$ & 36.24 & 8.20 & $5.65^{\mathrm{c}}$ & $0.883^{\mathrm{c}}$ & $6.51^{\mathrm{c}}$ \\
\hline $\mathbf{T}_{\mathbf{3}}$ & 36.16 & 8.23 & $6.29^{\mathrm{b}}$ & $0.821^{\mathrm{d}}$ & $5.81^{\mathrm{d}}$ \\
\hline $\mathbf{T}_{\mathbf{4}}$ & 36.29 & 8.20 & $6.92^{\mathrm{a}}$ & $0.750^{\mathrm{e}}$ & $5.42^{\mathrm{e}}$ \\
\hline
\end{tabular}

a-e: Means with different letters within a column are significantly different from each other at $\alpha=0.05$ as determined by Duncan's multiple range tests.

Table 2: Chemical composition (\%) of ice cream mixes with different ratios of WPC as a partial substitution of milk solid not fat.

\begin{tabular}{|c|c|c|c|c|c|c|l|}
\hline Treatments & Acidity & $\mathbf{p H}$ & SG (-) & W/gal (Ib) & FP $\left(^{\circ} \mathbf{C}\right)$ & Con.(sec) & AV(c.p) \\
\hline Control & $0.21^{\mathrm{c}}$ & $6.72^{\mathrm{a}}$ & $1.108^{\mathrm{a}}$ & $9.244^{\mathrm{a}}$ & $-2.47^{\mathrm{a}}$ & $44.13^{\mathrm{e}}$ & $45.65^{\mathrm{e}}$ \\
\hline $\mathbf{T}_{1}$ & $0.21^{\mathrm{c}}$ & $6.72^{\mathrm{a}}$ & $1.093^{\mathrm{a}}$ & $9.037^{\mathrm{b}}$ & $-2.41^{\mathrm{ab}}$ & $51.66^{\mathrm{d}}$ & $47.8^{\mathrm{d}}$ \\
\hline $\mathbf{T}_{2}$ & $0.22^{\mathrm{c}}$ & $6.55^{\mathrm{b}}$ & $1.082^{\mathrm{a}}$ & $9.012^{\mathrm{b}}$ & $-2.35^{\mathrm{ab}}$ & $60.50^{\mathrm{c}}$ & $55.57^{\mathrm{c}}$ \\
\hline $\mathbf{T}_{3}$ & $0.23^{\mathrm{bc}}$ & $6.47^{\mathrm{c}}$ & $1.080^{\mathrm{a}}$ & $9.011^{\mathrm{b}}$ & $-2.27^{\mathrm{ab}}$ & $74.59^{\mathrm{b}}$ & $60.2^{\mathrm{b}}$ \\
\hline $\mathbf{T}_{4}$ & $0.26^{\mathrm{a}}$ & $6.41^{\mathrm{d}}$ & $1.078^{\mathrm{a}}$ & $9.004^{\mathrm{b}}$ & $-2.19^{\mathrm{b}}$ & $82.67^{\mathrm{a}}$ & $65.65^{\mathrm{a}}$ \\
\hline
\end{tabular}

a-e: Means with different letters within a column are significantly different from each other at $\alpha=0.05$ as determined by Duncan's multiple range tests

Table 3: Physicochemical and rheological properties of ice cream mixes with different ratios of WPC

$(\mathrm{p}<0.001)$. The differences in acidity values among treatments are due to the differences in chemical composition and mainly the protein content. Natural titratable acidity in milk and milk products is dependent on casein, albumin, phosphates, citrates and carbon dioxide [17]. Obtained results were in agreement with those of Tirumalesha et al. [18] and Patel et al. [3]. The pH values of ice cream mixes with WPC in base formula are presented in Table 3. The $\mathrm{pH}$ values of ice cream mixes decreased significantly by substituting MSNF by WPC in the base formula $(\mathrm{p}<0.001)$. The differences in $\mathrm{pH}$ values of ice cream mixes are related to the original composition and acidity. Student $\mathrm{T}$ test confirmed the significancy of increasing the WPC\% on the $\mathrm{pH}$ values of ice cream mixes with a tight correlation between both factors (0.964). The decline of $\mathrm{pH}$ values were attributed to the reduction of skimmed milk powder (SMP) which contains milk proteins and buffering salt system of phosphate and citrate [19]. The obtained results were in harmony with those obtained by Patel et al. [3] and Castro et al. [20].

Specific gravity and weight/gallon: The effect of replacing MSNF with WPC at different ratios on specific gravity (SG) of ice cream mixes was shown in Table 3 . The specific gravity values of ice cream mixes decreased by substituting MSNF with WPC in the recipe $(p<0.001)$. An inverse relationship was found between SG and the ratio of WPC added to the ice cream mix. Within treatments, no significant differences was found (LSD value $=0.1575$ at $\alpha=0.050$ ). Awad and Metwally [14] and Awad [21] mention that SG values of ice milk mix decreased by substituting SMP with total milk protein or rice flour in the recipes.

Weight/gallon is a reflection of SG as it is the product of multiplying SG by 8.34 . Values of weight/gallon are presented in Table 3 . The control ice cream had the highest weigh/gallon and differed significantly $(\mathrm{p}<0.01)$ from that of WPC. A negative correlation $(-0.779)$ indicated that the substitution of MSNF with WPC at ascending ratios decreased weight/gallon.

Freezing point $\left({ }^{\circ} \mathbf{C}\right)$ : Whey proteins, lactose and mineral salts in any given ingredient can be taken into account to efficiently manage water-to-ice freezing performance and transitioning. This, in turn, affects freezing conditions, mix performance and finished product qualities such as body (chew, bite) and texture (smoothness). Freezing point of ice cream mixture is directed proportionally to the number of particles in solution, type and molecular weight of the solutes in the mix. The more dissolved solids in the solution, the lower the freezing point. The freezing point varies with the composition of the mix and concentration of the soluble constituents within the mix. The freezing point of ice cream mixes was significantly affected by adding WPC to ice cream recipes $(\mathrm{p}<0.001)$. The mixes showed higher freezing points with substituting MSNF by WPC. Control treatments showed descending freezing point among all treatments $(\mathrm{LSD}=0.2306$ at $\alpha=0.05)$, while that with $4 \%$ WPC substitution $\left(\mathrm{T}_{4}\right)$ showed the highest. The high freezing point in treatments with WPC could be due to its lower lactose and other true solutions solutes with high protein contents [22]. The results obtained are in line with those of Patel et al. [3] and Awad [21].

\section{Rheological properties of ice cream mixes}

Consistency: The mix consistency was expressed as the flow time which defined as: the time (sec.) required to empty a constant volume of ice cream mix. The flow time was significantly increased $(\mathrm{p}<0.001)$ by incorporating WPC in ice cream formula as shown in Table 3 . The high flow time was a sign for improvement in product consistency. The flow time increase or consistency improvement correlated with the ratio added of WPC to the ice cream formula (0.994). The increase of flow time of ice cream mix could be related to the high viscosity of the mixes containing WPC. The results are in agreement with Haque and Ji [23] and Ruger et al. [2].

Apparent viscosity: Viscosity defined as the internal resistance of a substance to flow when a shear stress is applied. Viscosity behavior is influenced by the complex hydrodynamic properties (i.e., size, shape, and hydration potential) and independent on the shear rate and time, while, resistance to flow is caused essentially by molecular or ionic cohesion. Viscosity data are often derived from single-point measurements. Since such measurements give no information about the flow behavior (dependence on shear rate), data may be contradictory, especially if the flow curves (shear stress vs. strain) under consideration actually cross each other. The viscosity of a fluid may increase in a linear or non linear fashion with a transition from Newtonian to non Newtonian behavior as the total solids concentration is increased.

Table 3 presented the viscosity values of ice cream mixes contain WPC in base formula. The data cleared that the viscosity of ice cream mix was significantly affected $(\mathrm{p} \leq 0.001)$ by adding WPC as a part of total milk solids in base recipe. The increase in viscosity values of mixes contain WPC could be due to the higher protein contents and /or to the nature and type of protein added into formula. Several investigations showed that proteins and especially WPC increases the product viscosity if added to the formula [2,20,24-26] and Sadar [26].

Flow behavior model: To elucidate the basic flow behavior combination of ice cream mixes containing WPC, the changes in shear stress induced by changing the shear rate were investigated. A set of WPC\% ice cream was tested under increasing shear rate with constant strain and shear stress/shear rate relationship was shown in Figure 1. A typical Herschel-Bulkley behavior was observed, as linear best fitting lines of the shear stress/shear rate data of the control and WPC\% mixes crossed the y axe at 0 shear rates with yield stresses exhibited in all treatments. Higher substitution levels of WPC in ice cream mixes resulted in an upward shifting of the flow curve (building up of structure leading to increase in the sample viscosity). The shear stress increased in the treatments with increasing the ratio of WPC added $(\mathrm{p}<0.001)$ significantly $[19,27]$. 


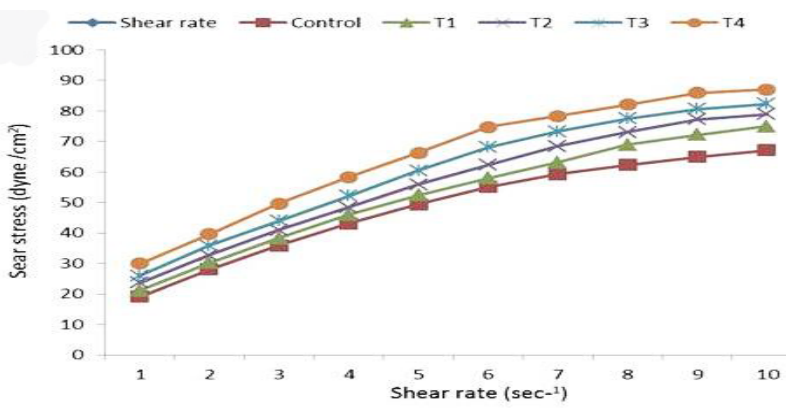

Figure 1: Flow behavior of ice cream mixes with different concentrations of WPC.

Yield stress values: Yield stress is defined as the minimum force required initiating flow. This means that subjecting a material to stress less than the yield stress will lead to a nonpermanent deformation or a slow creeping motion over the time scale of the experiment. Yield stress is related to the internal structure of the material which must be destroyed (overcome) before flow has occurred. Now, yield stress is routinely measured and used in the food industry not only for basic process calculations and manufacturing practices, but also as a test for sensory and quality indices and to determine the effect of composition and manufacturing procedures on structural and functional properties. The values of yield stress were calculated by fitting the shear stress and shear rate data to the Herschel-Bulkley equation:

$$
\sigma=\sigma_{0}+\eta_{a} \gamma
$$

Where $\sigma$, Shear stress; $\sigma_{0}$, Yield stress $=$ (shear stress at zero shear rate; $\eta_{\mathrm{a}}$, Apparent viscosity $[\mathrm{mPa} . \mathrm{s}] ; \gamma$, Shear rate.

The 'best fit' routine was used and the Herschel-Bulkley model was fitted with high regression coefficients, (Table 4) for all the samples, indicating a fitting model.

Power low equation: Flow behavior parameters of ice cream mixes as affected by WPC substitution were evaluated by fitting the shear stress/shear rate data to the power low equation [13]:

$$
\sigma=K \gamma^{n}
$$

Where $\sigma$, shear stress $\left[\right.$ dyne $\left./ \mathrm{cm}^{2}\right] ; \mathrm{K}$, consistency index $[\mathrm{mPa} . \mathrm{s}]=$ viscosity at $1 \mathrm{sec}^{-1} ; \gamma$, shear rate $\left[\mathrm{s}^{-1}\right] ; \mathrm{n}$, a dimensionless number that indicates the closeness to Newtonian flow. For a Newtonian liquid $\mathrm{n}$ is 1 ; for a dilatant fluid $\mathrm{n}$ is greater than 1 ; and for pseudoplastic fluid $\mathrm{n}$ is less than 1 .

Power law constants ( $\mathrm{k}$ and $\mathrm{n}$ ) were obtained using double logarithmic plot [28]. Power law constant and $\mathrm{R}^{2}$ values for $\log$-log plots for all treatments are given in Table 5. Flow behavior index (n) increased by the substitution of MSNF with WPC. The flow behavior index measures the degree of departure from Newtonian flow and results were consistent with pseudo-plastic flow for which " $n$ " is less than 1. However, addition of WPC had a little effect on " $n$ " value and maintained between 0.5-0.7 showing slight deviation from Newtonian flow. The consistency coefficient $(\mathrm{k})$ was more affected by the presence of WPC in the recipe than the flow behavior index (Table 5). The plots of the consistency index $(\mathrm{K})$ and the yield stress $\left(\sigma_{0}\right)$ were shown in Figure 2 . While, the $\mathrm{K}$ and $\mathrm{n}$ derived from the model were given in Table 5. The results were consistent with the observed plot, a shear thinning line that had a decreasing gradient $(n<1)$, their $\eta$ decreased with increasing shear. However, the presence of a yield stress values denotes a minimal stress which must be exceeded prior to flow occurring due to shear. This has been interpreted as the existence of a network structure, the bonds of which must be broken to allow flow.

Apparent viscosity-shear rate properties: Apparent viscosity values at a different shear rate (from 18.6 up to $186 \mathrm{sec}^{-1}$ ) are presented in Figure 3. Obtained results revealed a considerable decrease $(p<0.001)$ in viscosity with increasing shear rate at all concentration ranges of WPC. At the shear rate of $37.2 \mathrm{~s}^{-1}$ the curves leveled off and then decreased with the same constant until the maximum applied shear rate of $186 \mathrm{~s}^{-1}$. Such behavior is typical for a shear thinning system, so ice cream mix with different replacing ratio of WPC can be characterized as Herschel-Bulkley with shear thinning fluids, with the flow curves lacking a linear characteristic A rapid breakdown of the structure occurs on initial shearing followed by much slower changes at higher shear rates. This behavior can be attributed to combined effects of breakdown of weak links between the proteins and/or between the proteins and stabilizer, and of reformation of such links as a result of Brownian motion and molecular collisions [29].

Physicochemical properties of ice cream: Ice cream is a complex system with many ingredients in its formulation that can interact. The formulation as well as the actual processing conditions used in its manufacture can affect the final properties of the ice cream. However, the effect of WPC as a substitution of MSNF on some properties of resultant ice cream is presented in Table 6 .

Specific gravity: Specific gravity SG is one of the important physical properties of ice cream. It gives some information about the quality of the resultant ice cream such as body and texture, incorporated air and melting quality of ice cream. These data indicated that the SG of resultant ice cream decreased with incorporating WPC in the formula. The decrease in SG values correlated proportionally $(-0.966)$ with the added ratio of WPC. Specific gravity depends on the formula components as well as the ability of the mix to retain air cells in ice cream matrix. Ice cream treatment with $4 \%$ WPC in the formula $\mathrm{T}$ showed the lowest SG as the total protein was the highest $(6.92 \%)$ in comparison to the control mix (4.37\%), which meant more air incorporation in the body of ice cream with more protein membranes constructed. WPC\% affected the SG significantly $(\mathrm{p}<0.001)$ with high $R^{2}$. Within treatments, there was no significant differences between T3

\begin{tabular}{|c|c|c|c|}
\hline \multirow{2}{*}{ Treatments } & \multirow{2}{*}{ Liner equation } & \multicolumn{2}{|c|}{ Herschel-Bulkley equation } \\
\cline { 3 - 4 } & & Yield stress & $\mathbf{R}^{\mathbf{2}}$ \\
\hline Control & $\mathrm{y}=0.5526 \mathrm{x}+1.32$ & 1.32 & 0.995 \\
\hline $\mathrm{T}_{1}$ & $\mathrm{y}=0.5643 \mathrm{x}+1.39$ & 1.39 & 0.998 \\
\hline $\mathrm{T}_{2}$ & $\mathrm{y}=0.5465 \mathrm{x}+1.54$ & 1.54 & 0.996 \\
\hline $\mathrm{T}_{3}$ & $\mathrm{y}=0.5279 \mathrm{x}+1.69$ & 1.69 & 0.995 \\
\hline $\mathrm{T}_{4}$ & $\mathrm{y}=0.4909 \mathrm{x}+1.95$ & 1.95 & 0.993 \\
\hline
\end{tabular}

Table 4: Effect of WPC on yield stress of ice cream mixes.

\begin{tabular}{|c|c|c|c|c|}
\hline \multirow{2}{*}{ Treatments } & Liner equation & \multicolumn{4}{|c|}{$\begin{array}{c}\text { Flow parameters } \\
\text { Consistency } \\
\text { coefficient } \\
\text { K (dyne.S } / \mathbf{c m}^{2} \text { ) }\end{array}$} & $\begin{array}{c}\text { Flow behavior } \\
\text { index (n) } \\
(-)\end{array}$ & $\begin{array}{c}\text { Power } \\
\text { law } \\
\mathbf{R}^{\mathbf{2}}\end{array}$ \\
\hline Control & $\mathrm{y}=0.5844 \mathrm{x}+1.19$ & 3.29 & 0.584 & 0.994 \\
\hline $\mathrm{T}_{1}$ & $\mathrm{y}=0.580 \mathrm{x}+1.27$ & 3.53 & 0.580 & 0.998 \\
\hline $\mathrm{T}_{2}$ & $\mathrm{y}=0.567 \mathrm{x}+1.42$ & 4.14 & 0.567 & 0.997 \\
\hline $\mathrm{T}_{3}$ & $\mathrm{y}=0.5482 \mathrm{x}+1.57$ & 4.81 & 0.548 & 0.995 \\
\hline $\mathrm{T}_{4}$ & $\mathrm{y}=0.5104 \mathrm{x}+1.83$ & 6.23 & 0.510 & 0.993 \\
\hline
\end{tabular}

Table 5: Effect of WPC as a partial substitution of MSNF on the consistency (K) and flow behavior index $(n)$ of ice cream. 
Citation: El-Zeini Hoda M, Moneir El-Abd M, Mostafa AZ, Yasser El-Ghany FH (2016) Effect of Incorporating Whey Protein Concentrate on Chemical, Rheological and Textural Properties of Ice Cream. J Food Process Technol 7: 546. doi:10.4172/2157-7110.1000546

and $\mathrm{T} 4(\mathrm{LSD}=0.059$ at $\alpha=0.05)$. The results obtained are in line with those of [14].

Values of weight per gallon are also shown in Table 6. The weight per gallon (lb) values was calculated of SG values obtained for resultant ice cream formula; therefore, they follow the same trend as SG.

Overrun: Some well-known foods such as ice cream are produced by incorporating air into liquid and producing foam. The foam is stabilized by surface-active agents which is collected at the interface. The amount of air incorporated is expressed in term of overrun. An increase in volume of ice cream over that of ice cream mix by incorporating air is called overrun. Overrun percent in ice cream was significantly affected by adding WPC as MSNF substitution in the treatments $(\mathrm{p}<0.001)$. The more the protein, the more the protienious bubbles trapping air inside and resulting in high overrun $\left(\mathrm{R}^{2}=0.952\right.$, that was stated by Patel et al. [3]. The high overrun percentages in treatments containing WPC could be related to the high foaming ability of ice cream mixes. There are several factors that affect overrun in ice cream includes total solids in the mix and type of freezer used. The highest the total solids content, the greater the possible overrun [18,30-32]. Who pointed out that there was a significant improvement in both whipping rate and overrun by increasing the replacement of skim milk solids with the admixture of butter milk powder and WPC. Akalin [24] mentioned that the presence of WPC may facilitate the initial stabilization of newly formed air bubbles in the freezer better than UF retentates of NDM.

Texture profile analysis: Texture profile analysis method is widely used for texture evaluation of food products. Human eating action normally consists of several bites. In order to better describe the eating actions of human, the TPA test performs two bites every bite includes loading and unloading cycle. Texture profile analysis attributes of resultant ice cream as influenced by different replacing ratio of WPC and storage period are given in Figure 4. Fresh ice cream samples had hardness values of $66.77,60.85,50.30,44.23$ and $39.95(\mathrm{~N})$ for control, $\mathrm{T}_{1}, \mathrm{~T}_{2}, \mathrm{~T}_{3}$ and $\mathrm{T}_{4}$ treatments with $1,2,3$ and $4 \%$ WPC, respectively. Hardness of resultant ice cream was affected by replacing MSNF with $\mathrm{WPC}$ at different ratios and storage for 14 days at $-18 \pm 1^{\circ} \mathrm{C}(\mathrm{p}<0.001)$. The hardness values were lower in all treatments with WPC than control when fresh or after 14 days of storage, may be due to the higher overrun percentages. During storage, the hardness increased over that of fresh ice cream but decreased with storage proceeding and reached 70.37, 66.98, 62.50, 58.45 and $51.66(\mathrm{~N})$ for control, $\mathrm{T}_{1}, \mathrm{~T}_{2}, \mathrm{~T}_{3}$ and $\mathrm{T}_{4}$, respectively, may be due to shrinkage (air cell collapsing) results from a loss of discrete air bubbles in ice cream samples. Negative correlation $(-0.942)$ was obtained between WPC ratio and ice cream hardness, while low positive $(0.491)$ was found between storage period and hardness. Obtained results are in harmony with those represented by Tirumalesha and Jayaprakasha [18].

Adhesiveness is recognized as the work required to overcome the attractive forces between surface of the ice cream and surface of other materials with which the ice cream contacts. Data showed that the adhesiveness values were higher in all treatments with not only WPC but also storage period and the interaction of the two factors $(\mathrm{p}<0.001)$ than control with a correlation of 0.903 . During storage, adhesiveness values decreased gradually and significantly $(\mathrm{p}<0.001)$ to reach 8.56, 12.37, 16.84, 20.63 and $25.53(\mathrm{mj})$ for control, $\mathrm{T}_{1}, \mathrm{~T}_{2}, \mathrm{~T}_{3}$ and $\mathrm{T}_{4}$ treatments with 1, 2, 3 and $4 \%$ WPC, respectively (Figure 4 ).

Cohesiveness defined as the strength of internal bonds making up the body of the product, it is the ratio of the positive area during the second compression to that of the first peak during the first compression. results suggested that the internal structure of ice cream without added WPC was bonded and the bonds were stronger to break during the first compression than those of the ice cream with different ratios of WPC $(\mathrm{p}<0.001)$. During storage, there were little increasing in cohesiveness values (Figure 4$)$ over those of fresh ice cream $(\mathrm{p}<0.01)$. The increasing of obtained values may be correlated with the increasing of hardness in resultant ice cream. Cohesiveness negatively correlated with WPC\% (-0.767) and positive (0.0336) with storage period.

Hesion compares the strength between the internal bonds in a material to the strength of sticking of the material to any surface. If the former is higher than the later, the sample keeps its structure intact with less sticking force. If the reverse took place, the sample will rupture when pulled from the sticking surface which indicates loose structure. As indicated in Figure 4, the hesion was negative in all ice cream treatments which indicated a loose structure with weak internal bonds. WPC\% brought about a loose structure in favored of ice cream. Storage increased the hesion values leading to stronger and more compact structure which is unfavorable in ice cream.

Springiness (referred to as "elasticity") which is the rate at which a

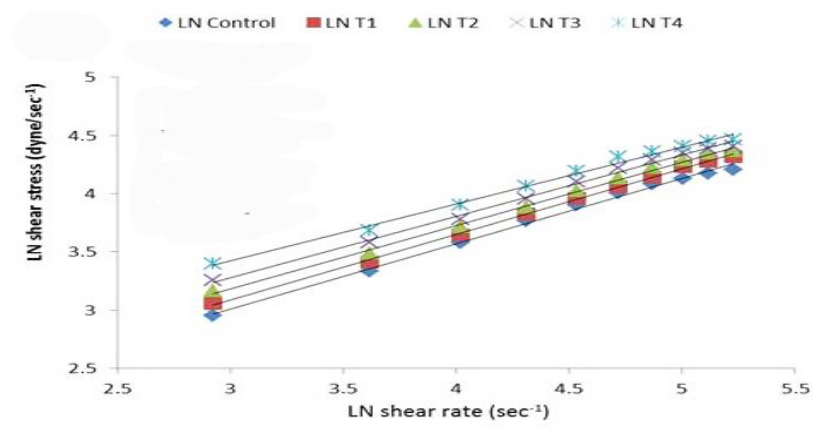

Figure 2: Double logarithmic plot for ice cream mixes with (WPC).

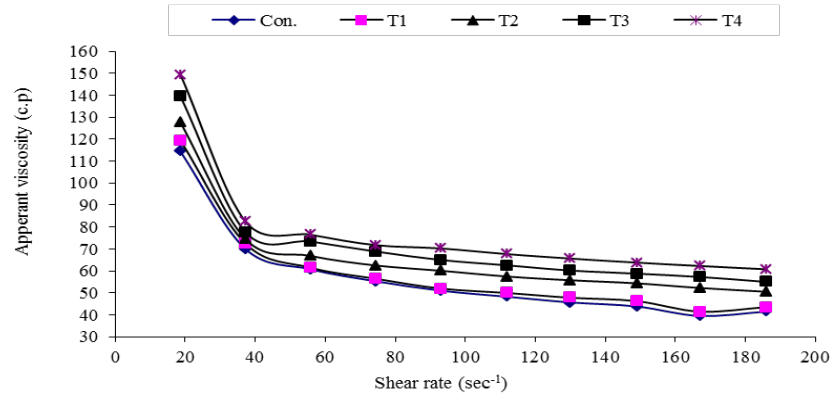

Figure 3: Effect of shear rate on viscosity of ice cream mixes with different ratios of WPC.

\begin{tabular}{|c|c|c|c|}
\hline Treatments & Specific gravity (-) & Weight per gallon (lb) & Overrun (\%) \\
\hline Control & $0.9133^{\mathrm{a}}$ & 7.6216 & $47.64^{\mathrm{d}}$ \\
\hline $\mathbf{T}_{1}$ & $0.8243^{\mathrm{b}}$ & 6.8784 & $54.23^{\mathrm{c}}$ \\
\hline $\mathbf{T}_{\mathbf{2}}$ & $0.7355^{\mathrm{c}}$ & 6.1379 & $61.95^{\mathrm{b}}$ \\
\hline $\mathbf{T}_{3}$ & $0.6914^{\text {cd }}$ & 5.7694 & $67.31^{\mathrm{a}}$ \\
\hline $\mathbf{T}_{4}$ & $0.6740^{\mathrm{d}}$ & 5.6252 & $69.94^{\mathrm{a}}$ \\
\hline
\end{tabular}

a-e: Means with different letters within a column are significantly different from each other at $\alpha=0.05$ as determined by Duncan's multiple range tests

Table 6: Effect of WPC\% on specific gravity and overrun ice cream properties. 

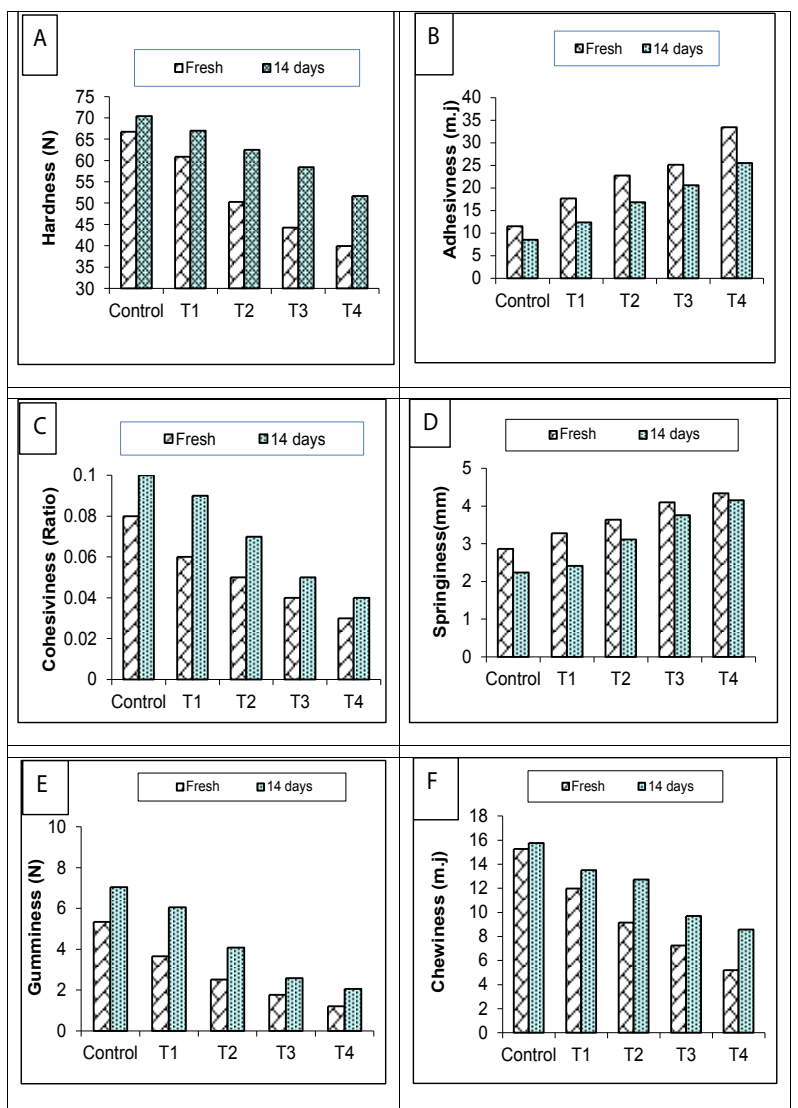

Figure 4: (a) Hardness, (b) Adhesiveness, (c) Cohesiveness, (d) Springiness, (e,f) Gumminess and Chewiness values of fresh and stored (14 days) ice cream with different replacing ratio of WPC.

deformed material returns to its original shape on removal of deforming force. Obtained data revealed that the springiness increased (Figure 4) proportionally $(\mathrm{p}<0.001)$ with increasing WPC\%. The springiness correlated positively $(0.823)$ with the quantity of WPC added to the ice cream formula and negatively with the storage period $(-0.333)$ with high $\mathrm{R}^{2}(0.889)$ for all treatments.

Gumminess, defined as "the energy required for disintegrating a semisolid food product to a state ready for swallowing," and is related to the primary parameters of hardness and cohesiveness (Figure 4). Ice cream gumminess decreased by increasing substitution level of WPC. There was a little increase of gumminess values during storage of ice cream samples at $-18 \pm 1^{\circ} \mathrm{C}$ for 14 days, which due to the increasing values of hardness and cohesiveness during the storage. Chewiness gives an indicator about the energy required to masticate the ice cream product to a state ready for swallowing. Chewiness values of ice cream decreased by increasing substitution levels of WPC. The chewiness values were lower (Figure 4) in all treatments with WPC than control which brought about by reducing hardness and cohesiveness values with the presence of WPC.

Sensory evaluation: Texture is a property difficult to evaluate with the use of a machine because it can only quantify the textural parameters in terms of a few specific characteristics, as it is a multi parameter characteristic, detected by several senses and derived from the food structure, texture is evaluated well by individuals who can perceive and describe all attributes of a product's texture [33]. Sensory panel evaluation is an important indicator of potential consumer preferences.

Sensory attributes evaluated were presented in Table 7. Panelists scored the $\mathrm{T}_{4}$, the least flavor. $\mathrm{T}_{3}$ was the most acceptable flavor among the ice cream (LSD $=0.4859$ at $0.05 \alpha$ level). Totally adding WPC enhanced the flavor significantly $(\mathrm{p}<0.001)$. All WPC ice cream received flavor ratings higher than control except $\mathrm{T}_{4}$, while $\mathrm{T}_{3}$ received the highest score for flavor. On the other hand, increasing the ratio of WPC lowered the flavor score. Incorporating WPC in ice cream formula up to $3 \%$ resulted in rich flavor, while with the higher ratio of WPC a slight unpleasant flavor was detected. Panelists did not observe any significant difference between $\mathrm{T}_{1}$ and $\mathrm{T}_{2}$ samples. Similarly, body and texture scores for ice cream showed no significant difference $\left(\mathrm{LSD}=0.4834\right.$ at 0.05 a level) between the control and $\mathrm{T}_{1} . \mathrm{T}_{1}$ with $1 \%$ WPC had more desirable scores, than $\mathrm{T}_{2}, \mathrm{~T}_{3}$ and $\mathrm{T}_{4}$ with 2,3 and $4 \%$ WPC, whereas control scored the highest (33.5), most desirable compared with all other treatments. WPC\% significantly decreased the obtained score $(\mathrm{p}<0.001)$ for overall texture acceptance compared with the control, that was insured by the negative correlation between WPC\% and body of the ice cream.

Ice cream containing $1 \% \mathrm{WPC}$ was smoother and gummier than ice cream containing higher ratios of WPC. It was likely due to the increase in protein content in ice cream mix as MSNF was substituted with WPC. Whey proteins had good water binding capacity and could be adsorbed onto ice crystals surface [3]. Hence, less free water was able to flow and form ice crystals, subsequently preventing large ice crystals formation and resulting in smoother texture in the ice cream containing WPC. Body and texture of ice cream scored had the same trend of flavour when judging body and texture. The differences among all treatments in body and texture are related to the effect of substitution level and the nature of proteins in WPC. At higher replacing ratio of WPC the texture appeared as a fluffy in resultant ice cream due to great incorporation percentage of air in relation to the percentage of total solids in the mix.

The meltdown properties of ice-cream constitute a critical performance parameter for the product so much, so that, in some cases, these properties contribute towards the formation of a quality judgment as important as the sensory properties of the product [34]. WPC\% played a central role in affecting meltdown behavior $(\mathrm{p}<0.001)$. The scores of melting properties for ice cream treatment with WPC as substitution of MSNF is shown in Table 7. The results indicated that there were significant improvements in melting quality of ice cream with adding WPC up to $3 \%$. Ice cream samples with WPC became slightly less melted and needed more time to melt which preferred by panelists (LSD value $=0.2919$ at $\alpha=0.050$ ), while with WPC higher ratio the ice cream became more susceptible to melting which is not

\begin{tabular}{|l|c|c|c|c|c|c|}
\hline \multirow{2}{*}{ Properties } & \multicolumn{5}{|c|}{ Treatments } \\
\cline { 3 - 8 } & Control & $\mathbf{T}_{1}$ & $\mathbf{T}_{2}$ & $\mathbf{T}_{3}$ & $\mathbf{T}_{4}$ \\
\hline Flavour & $(45)$ & $42.11^{\mathrm{c}}$ & $42.84^{\mathrm{b}}$ & $43.16^{\mathrm{b}}$ & $43.86^{\mathrm{a}}$ & $41.40^{\mathrm{d}}$ \\
\hline Body and texture & $(35)$ & $33.50^{\mathrm{a}}$ & $33.14^{\mathrm{a}}$ & $32.43^{\mathrm{b}}$ & $31.84^{\mathrm{c}}$ & $30.79^{\mathrm{d}}$ \\
\hline Melting properties & $(10)$ & $8.16^{\mathrm{c}}$ & $8.51^{\mathrm{b}}$ & $8.89^{\mathrm{a}}$ & $9.01^{\mathrm{a}}$ & $7.57^{\mathrm{d}}$ \\
\hline Appearance & $(10)$ & $8.2^{\mathrm{c}}$ & $8.5^{\mathrm{b}}$ & $8.57^{\mathrm{b}}$ & $8.9^{\mathrm{a}}$ & $8.5^{\mathrm{b}}$ \\
\hline Total & $(100)$ & 90.97 & 92.99 & 94.18 & 95.61 & 88.26 \\
\hline
\end{tabular}

a-e: Means with different letters within a column are significantly different from each other at $\alpha=0.05$ as determined by Duncan's multiple range tests

Table 7: Sensory quality attributes of ice cream samples with WPC as a partial substitution of milk solid not fat. 
Citation: El-Zeini Hoda M, Moneir El-Abd M, Mostafa AZ, Yasser El-Ghany FH (2016) Effect of Incorporating Whey Protein Concentrate on Chemical, Rheological and Textural Properties of Ice Cream. J Food Process Technol 7: 546. doi:10.4172/2157-7110.1000546

targeted. Negative low correlation $(-0.102)$ was obtained as a result of distorted trend associated with increasing WPC\%. The appearance sensory response to the ice cream samples was affected by the variation in WPC\%. Although these attributes are similar, the sensory panel found differences $(\mathrm{p}<0.001)$ for each percentage of WPC when scoring the samples for textural appearance.

\section{Conclusion}

Nutritional and functional properties can be enhanced by incorporating Whey protein concentrate as ingredient contains biologically active proteins as a substitute of the skimmed milk powder at $10,20,30$ and 40 per cent levels in the ice cream preparation. The WPC incorporated ice cream samples improved the melting quality of ice cream with adding WPC up to $3 \%$. The results reveal that the resultant ice cream has a higher sustainability in the mouth. Hence, it could be concluded that whey protein concentrate could be incorporated in the ice cream replacing skimmed milk powder with improved sensory properties besides improving the protein content of the ice cream.

\section{References}

1. Goff HD (1997) Colloidal aspect of ice cream, a review. Int Dairy J 7: 363-373.

2. Ruger PR, Baer RJ, Kasperson KM (2002) Effect of double homogenization and whey protein concentrate on the texture of ice cream. J Dairy Sci 85: 16841692.

3. Patel MR, Baer RJ, Acharya MR (2006) Increasing the protein content of ice cream. J Dairy Sci 89: 1400-1406.

4. Tabilo G, Flores M, Fiszman SM, Toldra F (1999) Postmortem meat quality and sex affect textural properties and protein breakdown of dry-cured ham. Meat Sci 51: 255-260

5. AOAC (2006) Official Methods of Analysis of the Association of Officia Analytical Chemists. Association of Official Analytical Chemists, Arlington, Virginia, USA.

6. Arbuckle WS (1986) Ice cream. The AVI Publishing Company Inc, Westport, USA.

7. Lawrance AJ (1968) The determination of lactose in milk products. Aust J Dairy Tech 23: 103-106.

8. Divide CL (1977) Laboratory Guide in Dairy Chemistry Practical. Dairy Training and Research Institute, Univ. of Philippines, Los Banos.

9. Winton AL (1958) Analysis of Foods, 3rd edn. P. 6. John. Wiley and Sons. Inc. New York, USA.

10. Kessler HG (1981) Food Engineering and Dairy Technology. Kessler, Freising Germany.

11. FAO (1977) Regional Dairy Development and Training Center for the Near East Laboratory Manual Spring.

12. Petersen BL, Dave RI, McMahon DJ, Oberg CJ, Broadbent JR, et al. (2000) Influence of capsular and ropy exopolysaccharide-producing Streptococcus thermophilus on Mozzarella cheese and cheese whey. J Dairy Sci 83: 1952-1956.

13. Benezech T, Maingnnat JF (1994) Characterization of the rheological properties of yoghurt. A review. J. Food Engineering 21: 447-472.

14. Awad RA, Metwally Al (2000) Evaluation of total milk proteinate as a milk solids source in ice cream manufacture. Annals Agric Sci, Ain Shams Uaniv, Cairo 45: 603-618.

15. Suneeta P, Prajapati JP, Patel AM, Patel HG, Solanky MJ, et al. (2007) Studies on the effect of whey protein concentrate in development of low-fat ice cream. Journal of Food Science and Technology 44: 586-590.

16. Parsons JG, Dybing ST, Coder DS, Spurgeon KR, Seas SW, et al. (1985)
Acceptability of ice cream made with processed whey and sodium caseinate. $J$ Dairy Sci 68: 2880-2885

17. Atherton VH, Newlander JA (1977) Chemistry and Testing of Dairy Products. AVI Publ Co, Inc, Westport, CT.

18. Tirumalesha A, Jayaprakasha HM (1998) Effect of admixture of spray dried whey protein concentrate and butter milk powder on physico-chemical and sensory characteristics of ice cream. Indian J Dairy Sci 51: 13-19.

19. Kerdchouay P, Surapat S (2012) Effect of skimmed milk substitution by whey protein concentrates in low-fat coconut milk ice cream.

20. Castro E, Silva C, Osorio F, Miranda M (2000) Characterization of caramel jam using back extrusion technique. Latin Amer Appl Res 30: 227-232.

21. Awad RA (2007) Performance of rice flour in ice cream manufacture. Proceedings of the 10th Egyptian Conference on Dairy Science \& Technology 517-534.

22. Muse MR, Hartel RW (2004) Ice cream structure elements that affect melting rate and hardness. J Dairy Science Association.

23. Haque ZU, Ji T (2003) Cheddar whey processing and source. Effect on non-fat ice cream and yoghurt. Inter J of Food Sci and Tech 38: 463-473.

24. Alvarez VB, Vodovotz WY, Ji T (2005) Physical properties of ice cream containing milk protein concentrates. J Dairy Sci 88: 862-871.

25. Akalin AS, Karagozlu C, Unal G (2008) Rheological properties of reduced-fat and low-fat ice cream containing whey protein isolate and inulin. Eur Food Res Technol 227: 889-895

26. Herald TJ, Aramouni FM, Abu- Ghoush MH (2008) Comparison study of egg yolks and egg alternatives in french vanilla Ice cream. J Text Stud 39: 284-295.

27. Sadar LN (2004) Rheological and textural characteristics of copolymerized hydrocolloid solutions containing curdlan gum.

28. Parnell-Clunies EM, Kakuda JM, Deman (1986) Influence of heat treatment of milk on the flow properties of yoghurt. J Food Sci 51: 1459-1462.

29. Tang Q, Munro PA, McCarthy OJ (1993) Rheology of whey protein concentrate solution as a function of concentration, temperature, $\mathrm{pH}$ and salt concentration. $\mathrm{J}$ of Dairy Research 60: 349-361.

30. Tomer V, Kumar A (2013) Development of high protein ice-cream using milk protein concentrate. IOSR Journal of Environmental Science, Toxicology and Food Technology (IOSR-JESTFT) 6: 71-74.

31. Pandiyan C, Kumaresan G, Annal Villi R, Rajarajan G (2010) Incorporation of whey protein concentrate in ice cream. Int J Chem Sci 8: 563-567.

32. Alfaifi MS, Stathopoulos CE (2010) Effect of egg yolk substitution by sweet whey protein concentrate (WPC), on physical properties of Gelato ice cream. International Food Research Journal 17: 787-793.

33. Mazaheri-Tehrani M, Yeganehzad S, Razmkhah-sharabiani S, Amjadi H (2009) Physicochemical and Sensory Properties of Peanut Spreads Fortified with Soy Flour. World Applied Sciences Journal 7: 192-196.

34. Tharp B, Gottemoller T, Kilara A (1992) The role of processing in achieving desirable properties in health responsive frozen dessert. Proceedings of Pennsylvania State Ice Cream Centennial Conference, Pennsylvania State University 227-246. 